\title{
Evaluation of the effect of red guava (Psidium guajava) fruit extract on tyrosinase (EC 1.14.18.1) activity by spectrophotometry
}

\author{
*Ayik Rosita Puspaningtyas \\ Department of Chemistry, Faculty of Pharmacy, Jember University, Kalimantan Street I No 2 Jember, Indonesia
}

\begin{abstract}
Tyrosinase is one of the most important enzymes in melanin biosynthesis. Inhibition of tyrosinase activity will cause a decrease in melanin production. Tyrosinase inhibitory activity by ascorbic acid has been studied before. Based on reported experiments, ascorbic acid can inhibit tyrosinase activity in enzymatic reaction competitively. As an effort to find out a skin whitening agent which is effective, safe and have minimum adverse effect, the inhibitory activities of Psidium guajava extract was studied on tyrosinase activity. This is one of the fruits that contains high amount of ascorbic acid. To determine the efficacy of tyrosinase inhibition, L-tyrosine was used as the substrate, P. guajava extract as inhibitor and ascorbic acid as positive control that was measured by spectrophotometry. The optimization of method was also performed. The inhibitory kinetics was determined by measuring the absorbance of dopachrome as the end product of the tyrosinase reaction. Michaelis-Menten constant $\left(\mathrm{K}_{\mathrm{m}}\right)$ and maximum velocity $\left(\mathrm{V}_{\max }\right)$ of the tyrosinase were determined by Lineweaver-Burk's plots. The $K_{m}$ and $V_{m a x}$ without the fruit extract were $0.315 \mathrm{mM}$ and $0.0265 \mu \mathrm{mol} / \mathrm{min}$. The $\mathrm{Km}$ value with the fruit extract of $1 \%, 2 \% \& 3 \% \mathrm{w} / \mathrm{v}$ were $0.4824,0.698 \& 0.543 \mathrm{mM}$, while the $V_{\max }$ value were $0.0269,0.0283 \& 0.0255 \mu \mathrm{mol} / \mathrm{min}$, respectively. Lineweaver-Burk's plots in presence of $P$. guajava fruit extract showed that the extract inhibited tyrosinase competitively. From the plots, the IC 50 of the fruit extract was determined as $0.26 \mathrm{mM}$; the control in $0.26 \mathrm{mM}$ concentration inhibited $56.523 \%$. Finally, P. guajava fruit extract showed higher effect than ascorbic acid on Tyrosinase activity.
\end{abstract}

Key Words: Inhibitory kinetics, Psidium guajava, fruit extract, Tyrosinase, L-tyrosine.

\section{INTRODUCTION}

Indonesia is a tropical country with abundant sunlight exposure. Sunlight had important contribution for living creature on the earth. For human, it plays important role to convert pro vitamin $\mathrm{D}_{3}$ (7dehydrocolesterol) on epidermis into vitamin $\mathrm{D}$ (Anderson, 1953; Curto et al., 1999). On the contrary, sunlight may also cause negative impacts on human skin such as skin cancer and hyperpigmentation (Brown and Burns, 2002). Hyperpigmentation is caused by increased melanin production often appeared as local pigmentation or skin spot. Hyperpigmentation may be figured as blacker skin than normal skin colour (Brown and Burns, 2002). Melanin production is important to protect human skin against negative effects from ultraviolet radia-

\footnotetext{
*Corresponding Author:

Ayik Rosita Puspaningtyas

Department of Chemistry, Faculty of Pharmacy

Jember University, Kalimantan Street I No 2

Jember, Indonesia

E-mail: aixrose_pee@yahoo.co.id
}

tion. However, high melanin concentration and melanin accumulation cause hyperpigmentation and aesthetic problems.

Now-a-days, many skin lightening products are available in the market with various active compounds to reduce hyperpigmentation and for skin lightening. Principal mechanism of skin lightening products is melanin inhibition (melanogenesis) so that skin becomes more bright and white. Melanin can be inhibited with various mechanisms such as tyrosinase activity inhibition, decreasing tyrosinase synthesis and transferm, melanosit cytotoxic inhibition etc. (Briganti et al., 2003). Tyrosinase is one of the most important enzymes in the melanin biosynthesis. It is the responsible catalyst for L-tyrosine reaction in melanosit cells (Elsner and Maibach, 2000). L-tyrosine or 4-hydroxysiphenylalanin is precursor of melanin. Active compounds in skin lightening products usually inhibit tyrosinase activity such as kojic acid, hydroquinone, arbutin, 
Table 1: Reagent composition for determining kinetic parameters on tyrosinase activity.

\begin{tabular}{lcccc}
\hline \multirow{2}{*}{ Reagent } & \multicolumn{4}{c}{ L-tyrosine concentrations(mM) } \\
\cline { 2 - 5 } & $\mathbf{0 . 5}$ & $\mathbf{0 . 7 5}$ & $\mathbf{1}$ & $\mathbf{2}$ \\
\hline L-tyrosine & 1 & 1 & 1 & 1 \\
Tyrosinase & 0.5 & 0.5 & 0.5 & 0.5 \\
Mops buffer & 1.5 & 1.5 & 1.5 & 1.5 \\
\hline
\end{tabular}

Notes: All units are in millilitres.

aloesin, ascorbic acid, cinnamic acid, and salicylic acid (Briganti et al., 2003). But all of these chemical substances are not safe, for example, hydroquinone, mercury, azelaic acid, kojic acid, and Alpha Hydroxy Acids (AHAs) often causes irritation, skin burn, acute allergy, skin inflammation, skin damage and skin cancer (Lynde et al., 2006; Maeda and Fukuda, 1991; Mishima et al., 1988; Smith et al.; 1988; Nadesul, 2004). Thus, there is still room for research to find out suitable skin lightening agent preferably from natural products with minimum adverse effect (Maeda and Fukuda, 1991; Mishima et al., 1988; Smith et al.; 1998).

Red guajava (Psidium guajava) is one of the fruits that contains high amount of ascorbic acid. $100 \mathrm{~g}$ fruits of Psidium guajava contain an equivalent weight of 100mg ascorbic acid (Morton, 1987). Tyrosinase inhibitory activity of ascorbic acid has been studied before, and found that it can inhibit tyrosinase activity in enzymatic reaction competitively (Briganti et al., 2003). The current research was designed to evaluate the effect of Psidium guajava extract on tyrosinase activity by determining inhibitory kinetic and kinetic plots.

\section{MATERIALS AND METHODS}

\section{Materials}

Mushroom tyrosinase (Sigma Aldirch), L-tyrosine (Merck), $0.4 \mathrm{~N} \mathrm{HCl}$, Mops buffer, $1 \mathrm{~N} \mathrm{NaOH}$, ascorbic acid coated CVC type A from BASF, Psidium guajava fruit extract, $0.01 \mathrm{~N}$ iodine standard, amylum indicator and distilled water.

\section{Instruments}

UV-Vis Spectrophotometer (Hitachi, U-1800), micropipette (Soccorex, 100-1000 $\mu \mathrm{L}$ ), thermometer, $\mathrm{pH}$ meter, freeze dryer, analytical balance (Sartorius), volumetric flask, glass beaker.
Table 2: Reagent composition for determining kinetic and plots inhibition of Psidium guajava extract.

\begin{tabular}{lcccc}
\hline \multirow{2}{*}{ Reagent } & \multicolumn{4}{c}{ L-tyrosine concentration(mM) } \\
\cline { 2 - 5 } & $\mathbf{0 . 5}$ & $\mathbf{0 . 7 5}$ & $\mathbf{1}$ & $\mathbf{2}$ \\
\hline L-tyrosine & 1 & 1 & 1 & 1 \\
Tyrosinase & 0.5 & 0.5 & 0.5 & 0.5 \\
Mops buffer & 1.4 & 1.4 & 1.4 & 1.4 \\
Sample & 0.1 & 0.1 & 0.1 & 0.1 \\
\hline
\end{tabular}

Note: All units are in millilitres.

\section{Sample preparation}

a. Preparation of tyrosinase solution Mushroom tyrosinase $4.7 \mathrm{mg}$ (5370 unit) was diluted in $0.1 \mathrm{M}$ Mops buffer- $\mathrm{NaOH}$ ( $\mathrm{pH} 6.5$ ) to $100.0 \mathrm{ml}$. The solutions were separated into vials and kept in freezer.

b. Preparation of L-tyrosine solution

$45.5 \mathrm{mg}$ L-tyrosine was diluted in $0.1 \mathrm{M}$ Mops buffer- $\mathrm{NaOH}$ to $25.0 \mathrm{ml}(10.0 \mathrm{mM})$.

c. Preparation of Psidium guajava fruits extract

Psidium guajava fruit extract was collected from Psidium guajava fruit and homogenized by homogenizer, filtered and then dried by freeze dryer. $2.5 \%$, $5 \%$ and $10 \% \mathrm{w} / \mathrm{v}$ P. guajava were diluted in $0.1 \mathrm{M}$ Mops- $\mathrm{NaOH}$.

d. Preparation of ascorbic acid solution

$18.49 \mathrm{mg}$ Ascorbic acid was diluted in $0.1 \mathrm{M}$ Mops buffer- $\mathrm{NaOH}$ to $25 \mathrm{ml}(4.20 \mathrm{mM})$.

\section{Determination of ascorbic acid concentration}

$0.5 \mathrm{ml}$ Psidium guajava fruit extract was diluted in $50 \mathrm{ml}$ distilled water and titrated by $0.01 \mathrm{~N}$ iodine standard (16g KI/L) using amylum indicator. Distilled water was used as blank (Sudarmaji, 1996).

\section{Maximum wavelength dopachrome optimization}

This study was conducted by using Rodriquez and Flurkey method (Rodriquez and Flurkey, 1992). $0.5 \mathrm{ml}$ tyrosinase solution $(252.39 \mathrm{unit} / \mathrm{ml})$ and $1 \mathrm{ml}$ $0.1 \mathrm{M}$ Mops buffer- $\mathrm{NaOH}$ ( $\mathrm{pH}$ 6.5) were preincubated at $25^{\circ} \mathrm{C}$ for 5 minutes. $1 \mathrm{ml}$ L-tyrosine solution was added and scanned for $\lambda_{\max }$ of dopachrome by UV-Vis spectrophotometer in $600 \mathrm{~nm}-400 \mathrm{~nm}$. Maximum wavelength of dopachrome was determined where the highest absorbance occurred over the range. 
Table 3: Result of tyrosinase activity parameters.

\begin{tabular}{|c|c|c|c|c|c|}
\hline $\begin{array}{c}\text { [L-tyrosine] } \\
\text { (mM) }\end{array}$ & $\begin{array}{c}\text { 1/[L-tyrosine] } \\
\left(\mathrm{mM}^{-1}\right)\end{array}$ & $\begin{array}{c}\mathrm{V} \\
(\mu \mathrm{mol} / \mathrm{min})\end{array}$ & $\begin{array}{c}\text { V average } \\
\text { ( } \mu \mathrm{mol} / \mathrm{min})\end{array}$ & $\begin{array}{c}1 / \mathrm{V} \\
\left(\mu \mathrm{mol} / \mathrm{min}^{-1}\right)\end{array}$ & $\begin{array}{l}\text { 1/V average } \\
\left(\mu \mathrm{mol} / \mathrm{min}^{-1}\right)\end{array}$ \\
\hline 0.5 & 2 & $\begin{array}{l}0.017 \\
0.016\end{array}$ & 0.016 & $\begin{array}{l}60.453 \\
63.660 \\
\end{array}$ & 62.057 \\
\hline 0.75 & 1.33 & $\begin{array}{l}0.019 \\
0.019 \\
\end{array}$ & 0.019 & $\begin{array}{l}53.691 \\
52.689 \\
\end{array}$ & 53.190 \\
\hline 1 & 1 & $\begin{array}{l}0.021 \\
0.021\end{array}$ & 0.021 & $\begin{array}{l}48.048 \\
48.241\end{array}$ & 48.145 \\
\hline 2 & 0.5 & $\begin{array}{l}0.022 \\
0.022\end{array}$ & 0.022 & $\begin{array}{l}44.734 \\
44.610\end{array}$ & 44.672 \\
\hline
\end{tabular}

\section{Incubation time optimization}

Incubation time was determined by examining dopachrome absorbance every 5 minutes up to 25 minutes (Boyer, 1993).

\section{Determination of kinetic parameters of Tyrosinase activity}

This study used Boyer and Calzyme lab modification method. $0.5 \mathrm{ml}$ tyrosinase solution (252.39 unit $/ \mathrm{ml}$ ) and $1.5 \mathrm{ml} 0.1 \mathrm{M}$ Mops- $\mathrm{NaOH}(\mathrm{pH} 6.5)$ were pre-incubated at $25^{\circ} \mathrm{C}$ for 5 minute. Tyrosinase was added in various concentrations of L-tyrosine and then dopachrome absorbance was measured by UVVis spectrophotometer. $0.1 \mathrm{M}$ Mops buffer and $\mathrm{NaOH}$ pH 6.5 was used as blank. L-tyrosine concentrations were $0.5 \mathrm{mM}, 0.75 \mathrm{mM}, 1.0 \mathrm{mM}$, and 2.0mM. Reagent composition for determining kinetics parameter is shown in Table 1.

\section{Determination of kinetics and plots effects of Psidium guajava extract}

0.5ml Tyrosinase solutions (252.39 unit $/ \mathrm{ml}), 0.1 \mathrm{ml}$

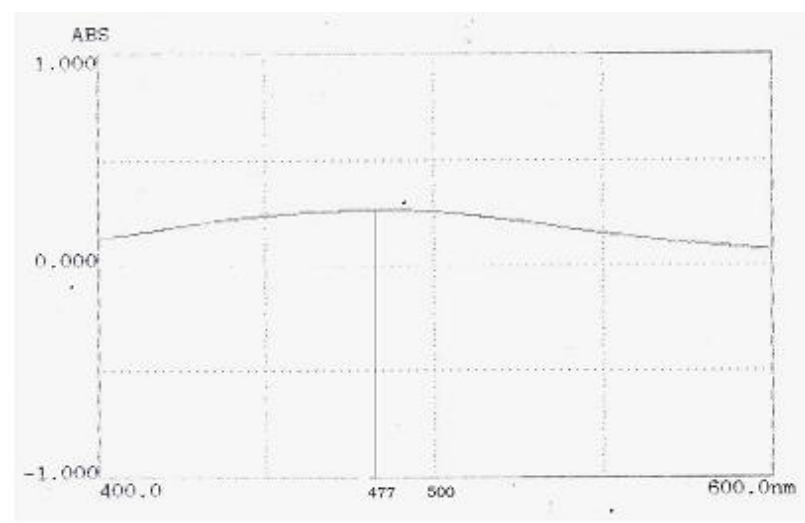

Figure 1: Result of maximum wavelength of dopachrome optimization.
Psidium guajava extract solutions and $1.4 \mathrm{ml} 0.1 \mathrm{M}$ Mops-NaOH ( $\mathrm{pH}$ 6.5) buffer were pre-incubated at $25^{\circ} \mathrm{C}$ for 5 minute. $1 \%, 2 \%$, and $3 \% \mathrm{w} / \mathrm{v}$ Psidium guajava extract concentrations in $0.1 \mathrm{ml}$ contain 0.029 , $0.06,0.08 \mathrm{mM}$, respectively. Finally, $1 \mathrm{ml}$ various concentrations of L-tyrosine was added and dopachrome absorbance was measured by UV-Vis Spectrophotometer at 10 and 20 minutes. $0.1 \mathrm{M}$ Mops buffer- $\mathrm{NaOH}$ was used as blank. Reagent composition for determining kinetic Psidium guajava extract is shown in Table 2.

\section{Determination of \% inhibition of ascorbic acid}

Procedure for determination of percentage inhibition value of ascorbic acid on tyrosinase activity was the same as Psidium guajava extract but ascorbic acid and only one concentration of L-tyrosine were used.

\section{Data analysis}

Determination of ascorbic acid concentration $1 \mathrm{ml} 0.01 \mathrm{~N}$ titrant of iodine standard is equivalent to $0.88 \mathrm{mg}$ ascorbic acid in Psidium guajava extract (Sudarmaji, 1996).

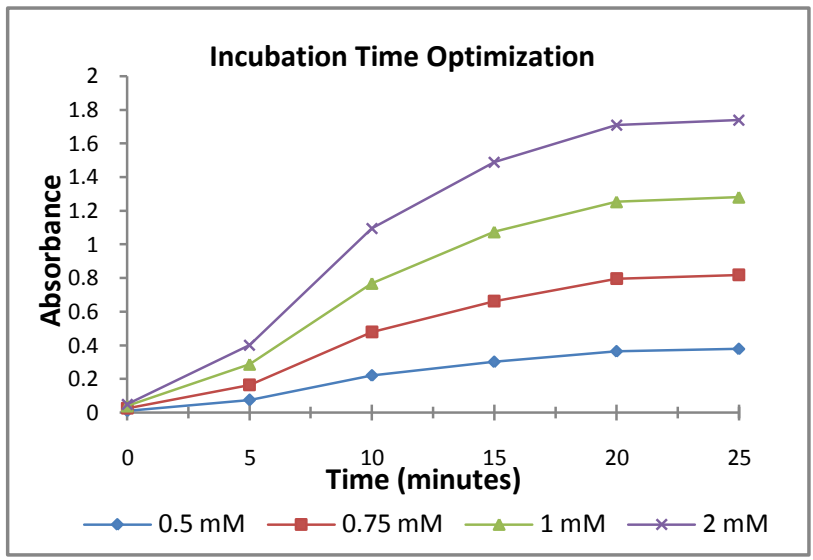

Figure 2: Result of incubation time optimization. 
Table 4: Kinetic parameters of tyrosinase activity value with and without Psidium guajava fruit extract.

\begin{tabular}{ccc}
\hline Enzymatic reaction & $\mathbf{K}_{\mathbf{m}}(\mathbf{m M})$ & $\mathbf{V}_{\max }(\mu \mathrm{mol} / \mathrm{minute})$ \\
\hline Without inhibitor & 0.3150 & 0.0265 \\
With inhibitor 1\% & 0.4824 & 0.0269 \\
With inhibitor 2\% & 0.6980 & 0.0283 \\
With inhibitor 3\% & 0.5430 & 0.0255 \\
\hline
\end{tabular}

Determination of kinetics and plots effects of Psidium guajava extract

This study used Lineweaver-Burk curve (Boyer, 1993) that shows relationship between enzymes activity ( $\mu \mathrm{mol} / \mathrm{minute}$ ) and substrate concentration ([S]). Conversion of $\Delta \mathrm{A} / \mathrm{min}$ value to $\mu \mathrm{mol} / \mathrm{minute}$ was done by Lambert Beer formula:

$c=\frac{\Delta A / \min }{E l}$

$\mathrm{c}=$ dopachrome concentration $(\mu \mathrm{mol} /$ minute $)$

$\Delta A /$ min $=$ changed absorbance per minute $\left(\right.$ minute $\left.^{-1}\right)$

$1=$ thickness of cuvette $(1 \mathrm{~cm})$

$\mathrm{E}=$ molar concentrations of dopachrome absorbance (3600/M.cm)

Inhibition percentage of Psidium guajava extract and ascorbic acid was calculated by following formula (from $\Delta \mathrm{A} / \mathrm{min}$ value) (Boyer, 1993):

\%inhibition $=\frac{(B-A) \times 100}{B}$

$A=$ rate of change absorbance value $(\Delta \mathrm{A} / \mathrm{min})$ with sample

$\mathrm{B}=$ rate of change absorbance value $(\Delta \mathrm{A} / \mathrm{min})$ without sample

\section{RESULTS AND DISCUSSION}

Determination of ascorbic acid concentrations in Psidium guajava extract

105.72 gram Psidium guajava fruit was equal to $1.65 \mathrm{~g}$ ascorbic acid. Psidium guajava extract concentrations were $1 \%, 2 \%$, and $3 \% \mathrm{w} / \mathrm{v}$ and equal to $1.56 \mathrm{~g}, 3.12 \mathrm{~g}$ and $4.68 \mathrm{~g}$, respectively.

\section{Determination of $\lambda_{\max }$ of dopachrome}

Based on literature, maximum wavelength of dopachrome was $475 \mathrm{~nm}$ (Boyer, 1993). In this research maximum wavelength of dopachrome was found to be $477 \mathrm{~nm}$ (Figure 1).

\section{Incubation time optimization}

Incubation time of tyrosinase concentration 252.39 unit/ml and L-tyrosine in various concentrations 0.5 , $0.75,1.0$ and $2.0 \mathrm{mM}$ was 20 minutes. The result was showed in Figure 2. The optimum result of incubation time was 20 minute because after 20 minutes
Table 5: Comparison of inhibition percentage between Psidium guajava fruit extract as inhibitor and ascorbic acid as control.

\begin{tabular}{cccc}
\hline No. & Inhibitor & $\begin{array}{c}\text { Ascorbic Acid Con- } \\
\text { centration (mM) }\end{array}$ & \% inhibition \\
\hline 1 & sample 1\% & 0.029 & 17.391 \\
2 & sample 2\% & 0.060 & 26.087 \\
3 & sample 3\% & 0.080 & 30.435 \\
4 & sample IC 50 & 0.260 & 50.000 \\
5 & Control & 0.260 & 56.523 \\
\hline
\end{tabular}

the Michaelis-Menten curve became linear and differences of absorbance value was not significant.

\section{Determination of Tyrosinase activity}

This study employed Michaelis-Menten and Lineweaver-Burk curve to get $\mathrm{K}_{\mathrm{m}}$ and $\mathrm{V}_{\max }$ value. Lineweaver-Burk curve shows relationship between tyrosinase activity and L-tyrosine concentrations, resulting $\mathrm{K}_{\mathrm{m}}$ value and $\mathrm{V}_{\max }$ were $0.315 \mathrm{mM}$ and $0.0265 \mu \mathrm{mol} / \mathrm{minute}$, respectively. Results of Tyrosinase activity parameters are shown in Table 3. Michaelis-Menten and Lineweaver-Burk curve is shown in Figure 3 and Figure 4.

\section{Determination of sample inhibition plot}

The $K_{m}$ and $V_{\max }$ value were obtained in absence and presence of Psidium guajava fruit extract as inhibitor in various L-tyrosine concentrations and can be seen in Table 4 and Figure 5. This curve showed cross 2 cutting on y axis. The inhibitor changed $\mathrm{K}_{\mathrm{m}}$ value but not the $\mathrm{V}_{\max }$ value. Inhibition type of Psidium guajava fruit extract on tyrosinase activity was competitive inhibition and showed in Figure 5.

\section{Determination of \% inhibition from product formed} Inhibition percentage between Psidium guajava fruit extract as inhibitor and ascorbic acid as control is shown in Table 5. Psidium guajava is one of the fruits containing high amount of ascorbic acid. Tyrosinase is the most important enzymes in the melanin biosynthesis. Inhibition of tyrosinase activity will decrease in melanin production. Tyrosinase is involved as catalysis reaction in melanin production (melanogenesis), which are L-tyrosine hydroxylation become dihydroxyphenilalanin (DOPA), and oxidation of DOPA gives dopaquinone. Kinetic and type of inhibition were determined in vitro where dopachrome absorbance value was taken as tyrosi- 


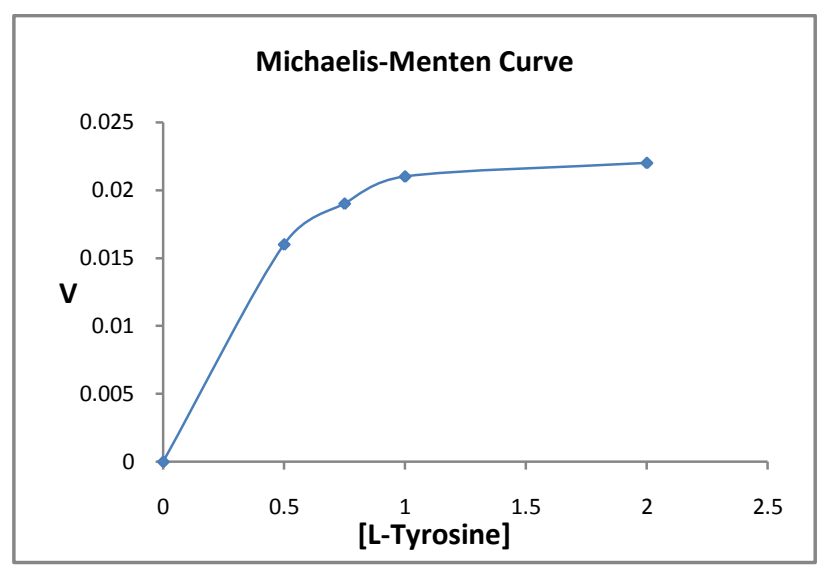

Figure 3: Relationship between tyrosinase activity and L-tyrosine concentrations by Michaelis-Menten curve.

nase activity parameter. $1 \%, 2 \%$ and $3 \% \mathrm{w} / \mathrm{v}$ Psidium guajava extract contained $0.029,0.060$, and $0.080 \mathrm{mM}$ ascorbic acid. The IC 50 of ascorbic acid on tyrosinase was $0.284 \mathrm{mM}$ (Schurink, 2007).

Determination of kinetic parameters of tyrosinase activity method used Boyer and Calzyme lab modification method. According the literature, suggested temperature is $25^{\circ} \mathrm{C}-30^{\circ} \mathrm{C}$. The research condition and spectrophotometer was at room temperature $\left(25 \pm 2^{\circ} \mathrm{C}\right)$ and at $30^{\circ} \mathrm{C}$, respectively. Buffer with a $\mathrm{pH}$ of $6.5 \pm 0.05$ was used. Optimum $\mathrm{pH}$ for tyrosinase catalysis reaction in the literature was found to be 6.5-7. Dopachrome has chromophore groups such as double bonds $\mathrm{C}-\mathrm{O}$ in benzene rings that can absorb light. Double bonds conjugation may decrease electron transition energy and increase wavelength. 0.5 $\mathrm{ml}$ Enzyme was used in every procedure at a concentration of 252.39 unit $/ \mathrm{ml}$. According to the literature, tyrosinase concentration was 100-200 unit and absorbance value was $0.2-0.8$ because it is free from noise. Determination of kinetics of tyrosinase activity was carried out at 10 and 20 minutes. Then rate of absorbance per minute $(\Delta \mathrm{A} / \mathrm{min})$ was calculated. $\Delta \mathrm{A} / \mathrm{min}$ value showed the alteration of dopachrome concentration every minute ( $\mu \mathrm{mol} / \mathrm{minute})$ using Lambert Beer formula. Inactivation of reaction such as added methanol, TCA (trichloroacetic acid), extreme temperature was not done because they can cause damage of dopachrome and tyrosinase enzymes. Dopachrome was counted in $\mu \mathrm{mol} / \mathrm{minute}$ and showed tyrosinase activity in various L-tyrosine concentration.

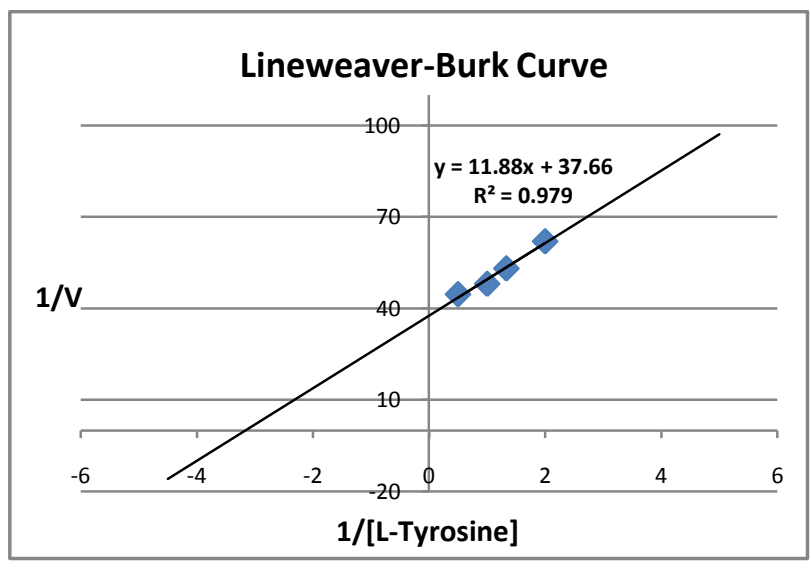

Figure 4: Relationship between tyrosinase activity and L-tyrosine concentrations by Lineweaver-Burk curve.

Regression resulted by Lineweaver-Burk curve in Figure 4 is used to determine $\mathrm{K}_{\mathrm{m}}$ and $\mathrm{V}_{\max }$ values which were $0.315 \mathrm{mM}$ and $0.027 \mu \mathrm{mol} / \mathrm{minute}$, respectively. The effects of Psidium guajava extract on tyrosinase activity was determined by LineweaverBurk curve and showed by cutting kinetic regression in y axis. Psidium guajava extract can give competitive effects on tyrosinase activity (Figure 5). The figure showed that $K_{m}$ value is changed while $\mathrm{V}_{\max }$ value remains constant. Table 5 showed that \% inhibition of Psidium guajava extract decreases with increased L-tyrosine concentration. So, it is clear that the mechanism of enzymatic reaction was competitive (Boyer, 1993). Competitive inhibition of Psidium guajava extract was caused by ascorbic acid.

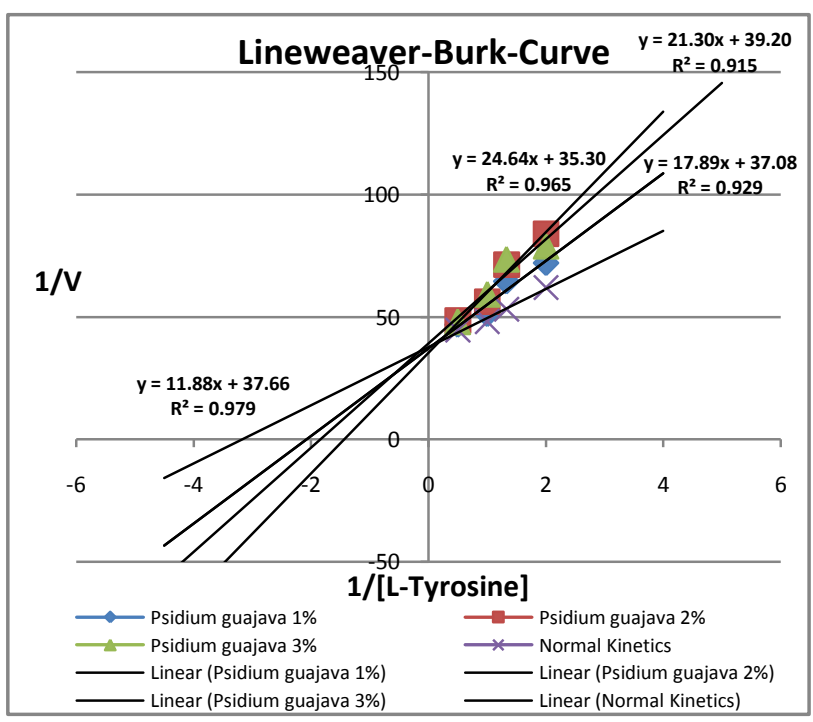

Figure 5: Relationship between enzymes kinetics with and without inhibitor. 
Ascorbic acid inhibited tyrosinase activity by interaction with cuprum $\left(\mathrm{Cu}^{2+}\right)$ ion as cofactor in active site of tyrosinase. Ascorbic acid is an antioxidant that oxidised faster than L-DOPA in oxidation cycle and then decreases dopaquinon production (Briganti, 2003). Furthermore, to prove the inhibition mechanism of Psidium guajava extract on tyrosinase activity, we need L-DOPA as substrate to know inhibition mechanism of tyrosinase in cresolase or catecholase activity on the next study. Percentage inhibition of $0.260 \mathrm{mM}$ ascorbic acid on tyrosinase activity and $1 \mathrm{mM}$ L-tyrosine concentration was $56.523 \%$. According to the literature IC 50 of ascorbic acid is $0.284 \mathrm{mM}$ (Schurink, 2007). Difference of this value was caused by usage of different substrate.

\section{CONCLUSION}

Psidium guajava extract can inhibit tyrosinase activity by competitively changing the $\mathrm{K}_{\mathrm{m}}$ value and constant in $V_{\max }$ value. $K_{m}$ values of $1 \%, 2 \%$ and $3 \%$ $\mathrm{w} / \mathrm{v}$ concentration of Psidium guajava extract were $0.4824,0.6980$ and 0.5430 , respectively, whereas $V_{\max }$ values were $0.0269,0.0283$ and $0.0255 \mu \mathrm{mol} / \mathrm{min}$, respectively.

\section{ACKNOWLEDGEMENT}

The author expresses gratefulness to Jember University, for providing fund for the research. The author is also grateful to the Department of Chemistry, Jember University for providing the facilities to execute this study.

\section{REFERENCES}

Anderson, A.K. (1953). Essential of Physiological Chemistry, $4^{\text {th }}$ edition, London. John Wiley \& Sons.

Boyer, R.F. (1993). Modern Experimental Biochemistry, $2^{\text {nd }}$ edition, pp.229-320, California: The Benjamin/ Cumming Publishing Co.

Briganti, S., Camera, E., and Picardo, M. (2003). Chemistry and Instrumental Approaches to Treat Hyperpigmentation. Pigment Cell Research, 16(2): 101-110. DOI PMid:12622786

Brown, R.G. and Burns, T. (2002). Lecture Notes on Dermatology, Adapted by Zakaria. Lecture Notes on Dermatology. Erlangga, Jakarta.

Curto, E.V., Kwong, C., Hermersdorfer, H., Glatt, H., Santis, C., Virador, V., Hearing, V.J., and Dooley, T.P. (1999). In- hibitors of mammalian melanocyte tyrosinase: in vitro comparisons of alkyl esters of gentisic acid with other putative inhibitors, Biochem. Pharmaco. 57(6): 663-672. DOI

Elsner, P. and Maibach H.(2000). Cosmeceuticals : Drug vs Cosmetics (pp. 123-143). New York. Marcel Dekker, Inc

Lynde, C.B., Kraft, J.N. and Lynde, C.W. (2006) Topical Treatments for Melasma and Postinflammatory Hyperpigmentation. Skin therapy letter, volume 11(9). (URL: Website) [Accessed on $3^{\text {rd }}$ June 2011]

Maeda, K. and Fukuda, M. (1991). In vitro effectiveness of several whitening cosmetic components in human melanocytes, J. Soc. Cosmet. Chem., 42: 361-368.

Mishima, Y., Hatta, S., Ohyama, Y. and Inazu, M. (1988). Induction of melanogenesis suppression: cellular pharmacology and mode of differential action, Pigment Cell Res., 1(6): 367-374. DOI PMid:3148920

Morton, J. Guava. In: J.F. Morton (1987) Fruits of warm climates (pp.356-363). Maimi, FL. Julia F. Morton.

Nadesul, H. (2004). Awas!Pemutih kulit mengandung merkuri (URL: Website) [Accessed on $10^{\text {th }}$ August, 2011]

Rodriquez, M.O. and Flurkey, W.H. (1992). A biochemistry project to study mushroom tyrosinase: Enzyme localization, isoenzymes, and detergent activation, J. Chem. Educ., 69(9): 767. DOI

Schurink, M. (2007). Peptides as inhibitors of lipoxygenase and tyrosinase. J. Biochem. 199: 259-262.

Smith, C.J., Ohare, K.B. and Allen, J.C. (1988). Selective Cytotoxicity of Hydroquinone for Melanocyte-Derived Cells is Mediated by Tyrosinase Activity but Independent of Melanin Content, Pigment Cell Res., 1(6): 386-389. DOI PMid:3148923

Sudarmaji, S. (1996). Prosedur Analisa untuk Bahan Makanan dan Pertanian (pp.26-27). Yogyakarta. Liberty 